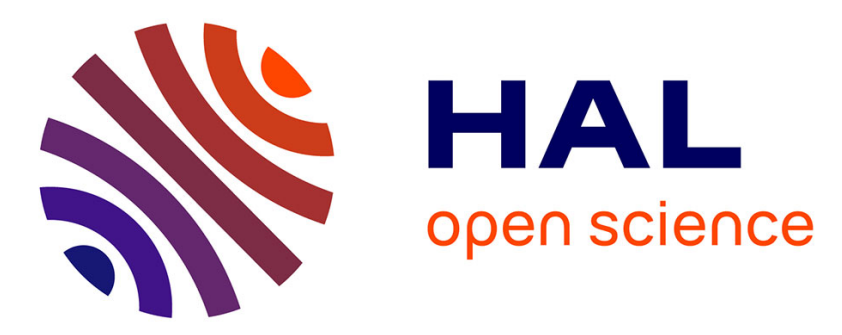

\title{
Fate of phthalic acid esters during composting of both lagooning and activated sludges
}

Soumia Amir, Mohamed Hafidi, Georges Merlina, Hassan Hamdi, Abdelmajid Jouraiphy, Mohamed El Gharous, Jean-Claude Revel

\section{To cite this version:}

Soumia Amir, Mohamed Hafidi, Georges Merlina, Hassan Hamdi, Abdelmajid Jouraiphy, et al.. Fate of phthalic acid esters during composting of both lagooning and activated sludges. Process Biochemistry, 2005, vol. 40, pp. 2183-2190. 10.1016/j.procbio.2004.08.012 . hal-00793423

\section{HAL Id: hal-00793423 \\ https://hal.science/hal-00793423}

Submitted on 22 Feb 2013

HAL is a multi-disciplinary open access archive for the deposit and dissemination of scientific research documents, whether they are published or not. The documents may come from teaching and research institutions in France or abroad, or from public or private research centers.
L'archive ouverte pluridisciplinaire HAL, est destinée au dépôt et à la diffusion de documents scientifiques de niveau recherche, publiés ou non, émanant des établissements d'enseignement et de recherche français ou étrangers, des laboratoires publics ou privés. 


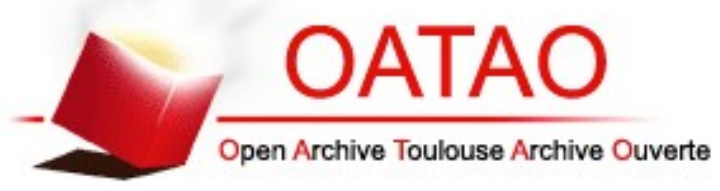

\section{Open Archive Toulouse Archive Ouverte (OATAO)}

OATAO is an open access repository that collects the work of Toulouse researchers and makes it freely available over the web where possible.

This is an author-deposited version published in: http://oatao.univ-toulouse.fr/ Eprints ID: 5815

To link to this article: DOI:10.1016/j.procbio.2004.08.012

http://dx.doi.org/10.1016/j.procbio.2004.08.012

To cite this version: Amir, S. and Hafidi, M. and Merlina, Georges and Hamdi, H. and Jouraiphy, A. and El Gharous, M. and Revel, Jean-Claude Fate of phthalic acid esters during composting of both lagooning and activated sludges. (2005) Process Biochemistry, vol. 40 (nº). pp. 2183-2190. ISSN 1359-5113

Any correspondence concerning this service should be sent to the repository administrator: staff-oatao@inp-toulouse.fr 


\title{
Fate of phthalic acid esters during composting of both lagooning and activated sludges
}

\author{
S. Amir ${ }^{\mathrm{a}}$, M. Hafidi ${ }^{\mathrm{a}}$,* G. Merlina ${ }^{\mathrm{b}}$, H. Hamdi ${ }^{\mathrm{a}}$, A. Jouraiphy ${ }^{\mathrm{c}}$, \\ M. El Gharous ${ }^{\mathrm{c}}$, J.C. Revel ${ }^{\mathrm{b}}$ \\ ${ }^{a}$ Unité Sol et Environnement (Lab. Ecol. Végét.), Faculté des Sciences Semlalia, \\ Dépt. de Biologie, BP/2390 Marrakech, Morocco \\ ${ }^{\mathrm{b} J . E . ~ A g r o n o m i e, ~ E n v i r o n n e m e n t ~ e t ~ E c o t o x i c o l o g i e, ~ E N S A T, ~} 31326$ Castanet-Tolosan, BP/ 107 Toulouse, France \\ ${ }^{\mathrm{c}}$ Centre d'arido-culture, INRA, Settat, Maroc
}

\begin{abstract}
Among the phthalic acid esters (PAEs) targeted by the United States Environmental Protection Agency (USEPA) as priority pollutants, diethyl-hexyl phthalate (DEHP) is the major pollutant identified at high concentration level in lagooning sludge (LS), at about $28.67 \mathrm{mg} / \mathrm{kg}$, and in activated sludge (AS), at about $6.26 \mathrm{mg} / \mathrm{kg}$. Other phthalic acid esters, such as di-butyl phthalate (DBP) and di-methyl phthalate (DMP) show very low concentrations. During sludge composting, after the stabilization phase, the subsequent appearance of DEP and then DMP occurred indicating that microbial metabolism begins by alkyl side-chain degradation before aromatic ring-cleavage. The appearance and accumulation of PAEs with a short alkyl side-chain in the last stages of AS and LS composting is suggested originating from the degradation of phthalates with a much long side-chain. The DEHP showed a rate of biodegradation that follows a first-order kinetic model during composting of both AS and LS. The calculated DEHP half-lives are 45.4 days for LS and 28.9 days for AS. The better DEHP biodegradation rate $\left(2.4 \times 10^{-2}\right.$ day $\left.^{-1}\right)$ have been observed in the case of AS composting compared to LS compost $\left(1.53 \times 10^{-2}\right.$ day $\left.^{-1}\right)$. The mono-ethylhexyl phthalates MEHP has been shown to follow the same order of biodegradation as DEHP indicating that the same mechanism is followed (hydrolysis or dealkylation of each DEHP side-chain). Composting could be suggested as a detoxification process for the removal of PAEs (mainly DEHP) from sludges after a sufficient time of treatment to provide a safe end product.
\end{abstract}

Keywords: Phthalic acid esters; DEHP; Composting; Lagooning sludges; Activated sludges; Biodegradation rate

\section{Introduction}

Phthalic acid esters (PAEs) are a class of refractory organic compounds widely used as additives or plasticizers in the manufacture of plastics. In order to improve the mechanical properties of a plastic resin, particularly flexibility, phthalate plasticizers are not bound covalently to the resin and can therefore migrate into the environment [1]. Due to the global use of plasticized plastics, phthalates have been detected in all environments in which they have been searched, even in medical material and urine [2].

\footnotetext{
* Corresponding author.

E-mail address: hafidi@ucam.ac.ma (M. Hafidi).
}

Some of these are suspected to be mutagens [3] and carcinogens [4]. Di-ethyl-hexyl phthalates (DEHP) is included in class B2 (probable human carcinogen) while benzyl butyl phthalate (BBP) belongs to class C (possible human carcinogen). Other phthalates: di-butyl phthalates (DBP), di-ethyl phthalates (DEP) and di-methyl phthalates (DMP) are included in class D (not classified as human carcinogens) [5]. However, questions about toxic effects of PAEs and their metabolites persist today [6]. The presence of PAEs mainly DEHP in sludge has been mentioned in numerous studies [7-9]. PAEs have been found in sewage sludge at levels of $12-1250 \mathrm{mg} / \mathrm{kg}$ [10]. In wastewater treatment plants, due to their low solubility, these substances tend to be concentrated in sludge through precipitation from 
the wastewater [7]. For this reason, the use of sewage sludge in agriculture could lead to human exposure either directly at the time of spreading or through the introduction of the compounds into the food chain. Therefore, it is required that sludge be exempt from such organic contaminants prior to its use. The reduction of PAEs content in sewage sludge is of great importance for further sludge disposal or agricultural utilization [11]. According to numerous studies, metabolic breakdown of PAEs by microorganisms under aerobic or anaerobic conditions is considered to be one of the major routes for the environmental removal of several PAEs from soil, natural water and wastewater [12-18]. Primary degradation half-lives range from less than 1 day to 2 weeks in surface and marine waters and from 1 week to several months in soil. Longer half-lives may occur in anaerobic conditions, oligotrophic or cold environments, or through the action of other limiting factors inhibiting biodegradation. Standardized aerobic biodegradation tests with sewage sludge inocula show that phthalate esters undergo more than 50\% ultimate degradation within 28 days [10]. Other studies demonstrate that compounds with short ester hydrocarbon chains are easily biodegraded and mineralized, and that PAEs with long ester chains are less susceptible to the degradation, some of them being considered recalcitrant [18-20]. Shelton et al. [21] found that DMP, DEP, DBP, BBP were mineralized in digested sludges whereas DEHP and di- $n$-octyl phthalates DOP were persistent. Banat et al. [11] show the influence of the sludge temperature and aeration rate on the reduction of DEHP concentration. A reduction of $70 \%$ was obtained for an air flow rate of $16 \mathrm{~m}^{3} / \mathrm{m}^{3} \mathrm{~h}$ and under a temperature of $63{ }^{\circ} \mathrm{C}$. Roslev et al. [22] and Madsen et al. [23] showed that the DEHP half lives in sludge-amended soil at $20{ }^{\circ} \mathrm{C}$ ranged from 10 to 60 days, but could exceed 300 days at 5$10{ }^{\circ} \mathrm{C}$.

Accordingly, the purpose of this work is to determine the levels of the PAEs targeted as priority pollutants by USEPA (DMP, DEP, DBP, BBP and DEHP) in both lagooning and activated sludges in Morocco and to assess the potential efficiency of composting as an aerobic thermophilic treatment allowing the removal of PAEs or diminution of their concentration level.

\section{Material and methods}

\subsection{Composting}

Lagooning sludge (LS) was taken from the anaerobic lagoon of an experimental wastewater treatment plant in Marrakech city (Morocco). Activated sludge (AS) was taken from the municipal wastewater treatment plant in Khouribga city (Morocco). A semi-industrial trial has been conducted on the lagooning sludge. A mixture of sludge $(165 \mathrm{~kg})$ and straw $(20 \mathrm{~kg})$ was composted on a platform and monitored over 180 days. For the activated sludge, an industrial trial
Table 1

Physico-chemical properties of initial samples and final compost of lagooning and activated sludge

\begin{tabular}{|c|c|c|c|c|}
\hline & \multicolumn{2}{|c|}{ Lagonning sludge } & \multicolumn{2}{|c|}{ Activated sludges } \\
\hline & $\begin{array}{l}\text { Initial } \\
\text { sample }\end{array}$ & $\begin{array}{l}\text { Final } \\
\text { compost }\end{array}$ & $\begin{array}{l}\text { Initial } \\
\text { sample }\end{array}$ & $\begin{array}{l}\text { Final } \\
\text { compost }\end{array}$ \\
\hline $\mathrm{pH}$ & 7.30 & 6.80 & 6.36 & 6.23 \\
\hline C. org (\%) & 17.74 & 13.45 & 35.7 & 20.55 \\
\hline M. org (\%) & 30.6 & 23.18 & 61.56 & 36.85 \\
\hline N. tot $(\mathrm{mg} / \mathrm{g} \mathrm{ps})$ & 7.42 & 8.82 & 12.00 & 16.90 \\
\hline $\mathrm{C} / \mathrm{N}$ & 24.00 & 15.24 & 29.75 & 12.16 \\
\hline DEC (\%) & - & 41.50 & - & 60.82 \\
\hline HA (mg/g ps) & 18.12 & 22.8 & 26.47 & 39.5 \\
\hline
\end{tabular}

All results expressed in dry basis; C. org: organic carbon; N. tot: tota nitrogen (Kjeldahl method); DEC: decomposition rate; HA: humic acids.

was conducted. A mixture of sludge (5 tons) and grass (2.5 tons) was composted on a platform and monitored for 135 days. For both trials, the mixture was turned over every 15 days to ensure aerobic conditions. The well progress of composting and microbial activities was followed by measuring daily the temperature in heaps of the compost.

\subsection{Sampling}

To obtain the representative samples and results of analysis, numerous samples from various point of the compost heaps were collected and mixed thoroughly at each stage of composting: The selected times of sampling were for lagooning sludge (initial mixture, after 30, 60, 90 and 180 days) and for activated sludge (initial mixture, after 15 , 30, 45, 75, 90 and 135 days). The samples were kept deep frozen until analysis.

\subsection{Compost parameters}

Some physico-chemical characteristics of the composts at different stages of treatment are reported in Table 1 . The $\mathrm{pH}$ is determined on a suspension sample-water $(10 \mathrm{~g} /$ $15 \mathrm{ml}$ ), the total organic carbon (C. org) is measured according to ANNE method, the total nitrogen (N. tot) by Kjeldahl method. The rate of decomposition is calculated after ignition of the dry sample at $550{ }^{\circ} \mathrm{C}(16 \mathrm{~h})$. The humic acid content was calculated after a freeze-drying of a known volume.

\subsection{PAE extraction}

For each sample, a homogenized air-dried quantity of about $10 \mathrm{~g}$ was used. PAE extraction was performed twice on this amount of matter with a mixture of $10 \mathrm{ml}$ of dichloromethane and $20 \mathrm{ml}$ of di-ethylether [8]. The mixture: solvents + sample was poured into a glass centrifugation tube with Teflon caps, shaken for $30 \mathrm{~min}$ and then centrifuged for $15 \mathrm{~min}$ at a rate of $2500 \mathrm{rpm}$. This procedure was repeated twice. The two extracts collected for each 
sample were pooled before being dried by filtration through anhydrous $\mathrm{Na}_{2} \mathrm{SO}_{4}$. The extracts were sufficiently clean to be directly analyzed.

\section{5. $G C-M S$ analysis}

GC-MS analysis was performed with a Hewlett-Packard gas chromatograph HP-5890 series II, equipped with a mass detector MSD HP-5971 and a data analysis station HP Chem. The column used for analysis was a $25 \mathrm{~m} \mathrm{HP}-5 \mathrm{MS}$ type (cross linked 5\% phenylmethylsilicone; $0.2 \mathrm{~mm}$ i.d., $0.33 \mu \mathrm{m}$ film thickness). As carrier gas, high-grade helium $\mathrm{N} 55$ was used at a flow rate of $0.89 \mathrm{ml} / \mathrm{min}$. Injection was made in split less mode. Injector temperature was $280{ }^{\circ} \mathrm{C}$ and the purge time was set to $1 \mathrm{~min}$.

The GC-MS oven temperature was maintained at $40{ }^{\circ} \mathrm{C}$ for $1.5 \mathrm{~min}$ and then increased at a rate of $30^{\circ} \mathrm{C} / \mathrm{min}$ until $160{ }^{\circ} \mathrm{C}$. The increase rate was then set to $5{ }^{\circ} \mathrm{C} / \mathrm{min}$ until the temperature reached $195{ }^{\circ} \mathrm{C}$. The next increase rate was then lowered to $3{ }^{\circ} \mathrm{C} / \mathrm{min}$ until $280^{\circ} \mathrm{C}$. This final temperature was held for $23 \mathrm{~min}$ to eliminate all co-extracts. The detector temperature was $300{ }^{\circ} \mathrm{C}$, and the EMV sensitivity was set to $2600 \mathrm{~V}$.

GC-MS analyses were compared with commercial standards and with library records from the National Institute of Standards (NIST).

\subsection{Chemicals and standards}

A standard solution was used containing a mix of five PAEs (DEHP, BBP, DBP, DEP and DMP) at $500 \mathrm{ng} / \mu \mathrm{l}$ in methanol supplied by Supelco (Bellefonte, PA, USA). A standard of mono-ethyl-hexyl phthalate (MEHP) could not be obtained commercially. All other chemicals and solvents were of analytical grade.

\subsection{Quantitation}

Data acquisition was carried out in the selected ion monitoring mode (SIM) using the following ions 225, 163, $149,104,91$ and $76 \mathrm{~m} / z$. Quantitation was based on the external standard technique utilizing integrated peak areas of each selected ion. To take the weight variations of the sludge mixture pile during composting into account, all measurements were expressed per unit ash. The latter constitutes the most chemically stable parameter during the composting process. The corrected values of the concentration at each step of composting were obtained from the following formula:

$C=C_{\mathrm{m}} \times\left(\frac{A_{0}}{A_{T}}\right)$

where $C_{\mathrm{m}}$ is the concentration measured by chromatography, $A_{0}$ the level of ash in the initial sample $T_{0}, A_{T}$ the level of ash in sample at each step $T$ of composting.
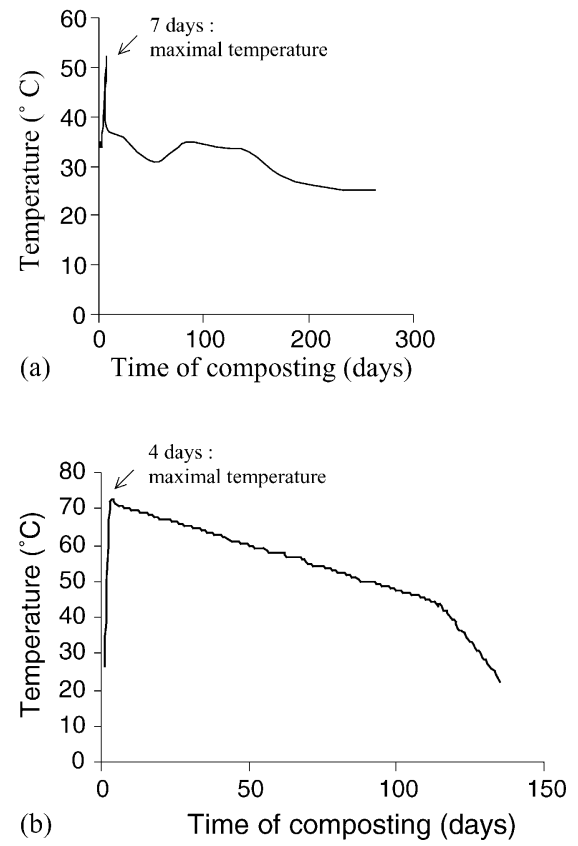

Fig. 1. Variation of temperature during composting of lagooning and activated sludges ( $\mathrm{a}$ and $\mathrm{b}$, respectively).

\section{Results and discussion}

\subsection{Compost processing}

The change of some physico-chemical parameters between initial samples and final composts are presented in Table 1. $\mathrm{pH}$ is the parameter which affects greatly the composting process. $\mathrm{pH}$ values were within the optimal range for development of bacteria 6-7.5 and fungi 5.5-8.0. Two phases of composting process were recorded: a phase of stabilization (about 30 days), where temperature has peaked to $52{ }^{\circ} \mathrm{C}$ after 7 days of lagooning sludge composting, and to $72{ }^{\circ} \mathrm{C}$ after 4 days of activated sludge composting (Fig. 1). The increase of temperature during stabilisation phase originated from a development of microbial activities, mainly thermophilic species. A second phase of maturation occurred after the first month of composting, is characterized by a decrease of temperature level ambient temperature. This phase is characterised by a development of mesophilic communities. The succession during composting of these microbial communities thermophile and mesophile allow biodegradation of raw materials. Since, a part of organic carbon was decreased and the other part was probably included in the formation of humic structures (Table 1). The $\mathrm{C} / \mathrm{N}$ ratio decreased from 24 to 15.4 and from 29.7 to 12.1 , respectively, in lagooning sludge and activated sludge. The rate of decomposition is recorded about $41.5 \%$ in the case of lagooning sludge and achieved $60.8 \%$ in the case of activated sludge. These variations allow to suggest the good processing of both trials of composting. 
Table 2

Fate of phthalic acid esters (PAEs) with short alkyl side-chains during composting of lagooning sludge (LS)

\begin{tabular}{|c|c|c|c|c|c|c|c|}
\hline $\mathrm{PAE}(\mathrm{mg} / \mathrm{kg})$ & Retention time (min) & Characteristic ion $(\mathrm{m} / \mathrm{z})$ & Initial sample & 30 days & 60 days & 90 days & 180 days \\
\hline \multirow[t]{2}{*}{ DMP } & 8.06 & 163 & - & 0.31 & 0.37 & 0.6 & 0.33 \\
\hline & & 104 & - & - & - & - & 1.16 \\
\hline \multirow[t]{3}{*}{ DEP } & 9.64 & 149 & - & 0.91 & - & - & 1.01 \\
\hline & & 104 & - & - & - & - & 0.85 \\
\hline & & 76 & - & - & - & - & 0.89 \\
\hline \multirow[t]{2}{*}{ DBP } & 15.65 & 225 & - & - & - & - & 3.09 \\
\hline & & 149 & 1.66 & - & - & - & - \\
\hline BBP & 24.52 & 225 & - & - & - & - & 8.8 \\
\hline
\end{tabular}

-: Not detected; DMP: di-methyl phthalate; DEP: di-ethyl phthalate; DBP: di- $n$-butyl phthalate; BBP: benzyl butyl phthalate.

\subsection{Levels of five common PAEs in lagooning and activated sludges}

The occurrence of five common PAEs (DEHP, BBP, DBP, DEP and DMP) was investigated in both composted lagooning and activated sludges.

Di-ethyl-hexyl phthalate (DEHP) was the main PAE identified at high concentration levels in the initial samples. It occurred at about $6.26 \mathrm{mg} / \mathrm{kg}$ dry weight in AS sludge and at about $28.67 \mathrm{mg} / \mathrm{kg}$ dry weight in LS sludge. These values are very low compared to those reported for the sludges of other countries, see the low industrial activities. The USA National Sewage Sludge Survey reported levels of DEHP ranging from 55.1 to $163.3 \mathrm{mg} / \mathrm{kg}$ dry weight [24]. Similar levels were reported in Canadian and Germany surveys $[9,25]$.

Di-butyl phthalate (DBP) was present in both initial sludge mixtures and di-methyl phthalate (DMP) was present only in AS at low concentrations (Tables 2 and 3).

The low concentration level of DEHP and DBP observed in the case of AS compared to LS could be attributed to high biological activity at the activated wastewater plant, in addition to the fact that the two sludges did not have the same origin. Otherwise, the high levels of DEHP and relatively high levels of DBP in LS sludges can be attributed to the weak biodegradation under the anaerobic or methanogenic conditions in the wastewater plant lagoon $[20,29,30]$.

Subba-Rao et al. [26] and Battersby and Wilson [27] reported that primary and sometimes ultimate degradation of PAEs occurred during sludge treatment. PAEs with short alkyl side-chains are easily decomposed, and this may explain the low level of DMP, DEP and DBP in both sludges (AS and LS). In contrast, some proportion of PAEs adsorbed by the suspended organic matter, the recalcitrant PAEs as DEHP and others with long side-chains, could escape microbial degradation during treatment in the wastewater plant [28].

\subsection{Fate of PAEs with short side-chains during composting}

During composting of both sludges, after the stabilization phase (30 days of composting), DBP disappeared in parallel with the appearance in lagooning sludge of shorter alkyl side-chain phthalates, such as di-ethyl phthalate (DEP) and DMP. In the next step of composting, DEP disappeared and the level of DMP remained almost constant in both sludge composts (Tables 2 and 3). Biodegradation of PAEs by microorganisms under aerobic conditions has been demonstrated in other studies carried out in soil, natural water, wastewater and sludges $[11,14]$. Therefore, the development of intense microbial activity during composting could be considered as the main factor leading to the biodegradation of the PAEs. Used as a source of energy, the microbial metabolism of the PAEs seems to begin by alkyl side-chain degradation before aromatic ring-cleavage. Fig. 2 summarizes various catabolic pathways of PAEs biodegradation reported in previous studies [18,31-36].

The appearance of di-ethyl phthalate (DEP), during composting, is probably due to $\beta$-oxidation of both alkyl side-chains of DBP. While di-methyl phthalate (DMP) may originate as described by Cartwright et al. [35] through

Table 3

Fate of phthalic acid esters (PAEs) with short alkyl side-chains during composting of activated sludge (AS)

\begin{tabular}{|c|c|c|c|c|c|c|c|c|c|}
\hline PAE $(\mathrm{mg} / \mathrm{kg})$ & Retention time (min) & Characteristic ion $(\mathrm{m} / \mathrm{z})$ & Initial sample & 15 days & 30 days & 60 days & 75 days & 90 days & 135 days \\
\hline DMP & 8.06 & 163 & 0.54 & 0.18 & 0.48 & 0.20 & 0.15 & 0.12 & - \\
\hline \multirow[t]{2}{*}{ DEP } & 9.64 & 149 & - & - & - & 0.9 & - & - & 2.07 \\
\hline & & 76 & - & - & - & - & - & - & 1.55 \\
\hline \multirow[t]{2}{*}{ DBP } & 15.65 & 225 & - & - & - & - & 0.30 & 1.66 & 6.25 \\
\hline & & 149 & 0.39 & - & - & 0.16 & - & - & - \\
\hline $\mathrm{BBP}$ & 24.52 & 225 & - & - & - & - & 2.64 & 14.17 & 13.94 \\
\hline
\end{tabular}

-: Not detected; DMP: di-methyl phthalate; DEP: di-ethyl phthalate; DBP: di- $n$-butyl phthalate; BBP: benzyl butyl phthalate. 
PAEs with long alkyl side-chain<smiles>CCCCCOC(=O)c1ccccc1C(=O)OCCCCC</smiles><smiles>CCCCCOC(=O)c1ccccc1C(=O)OCCCCC</smiles><smiles>CCCCC(C)COC(=O)c1ccccc1C(=O)OCC(C)CCCC</smiles><smiles>C=C=COC(=O)c1ccccc1C(=O)OCCCCC</smiles>

Di-(2-ethylhexyl) phthalate

(.......:

(ß-oxidation)<smiles>CCOC(=O)c1ccccc1C(=O)OCC</smiles>

Di-ethyl phthalate

(transesterification/ demethylation)<smiles>CCOC(=O)c1ccccc1C(=O)OC</smiles>

Ethyl-methyl phthalate

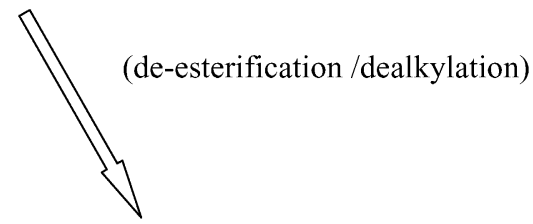<smiles>C=[Te]</smiles><smiles>COC(=O)c1ccccc1C(=O)OC</smiles>

Di-methyl phthalate<smiles>CCOC(=O)c1ccccc1C(=O)O</smiles>

Ethyl phthalate<smiles>C=C=Cc1ccccc1C(=O)OC</smiles>

Methyl phthalate

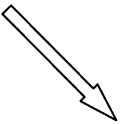<smiles>O=C(O)c1ccccc1C(=O)O</smiles>

Phthalic acid

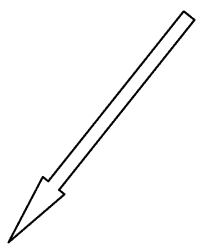

Cleavage of aromatic ring

Fig. 2. Major biodegradation pathways of phthalic acid ester (proposed in previous studies).

demethylation of both side-chains of DEP implying the cleavage of a relatively strong $\mathrm{C}-\mathrm{C}$ bond within the ethyl group. These authors have also suggested alternative pathways: the transesterification or the replacement of the ethyl group with a methyl group following the cleavage of the relatively weaker $\mathrm{C}-\mathrm{O}$ ester bond.

The non-appearance of DEP in AS compost may result from its stronger or more efficient biological activity 
compared to LS compost. A wide class of indigenous microbial communities has developed during treatment in the activated wastewater plant, and continue their activity during composting. Alatriste-Mondragon et al. [28] show that the half-life of DBP in anaerobic sludge is about 5 days. The estimated duration of ultimate degradation is then about 50 days. Wang et al. [37] reported that up to $1.25 \mathrm{mM}$ of DBP could be completely degraded within $100 \mathrm{~h}$ by a denitrifying bacterium isolated from activated sludge. Therefore, decomposition of DEP (DBP metabolite) may have been rapidly achieved in AS compost.

However, information about if the PAEs are subjected to biodegradation until ring-cleavage of aromatic cycle is lacked in this study. Because, GC-MS technique or experimental conditions as extraction appear with not adequate recovery about phthalic acid level.

In the last step of composting, both LS and AS sludges exhibited a high concentration of benzyl butyl phthalate (BBP), DBP and DEP after 180 days of composting for LS and 60 days of composting for AS (Tables 2 and 3). DMP also occurred in much higher concentrations in the case of LS compost. The increase of DBP, DEP and DMP contents at this stage of composting could be attributed to the microbial attack of the side-chain of PAEs with longer alkyl side-chains, which appears more efficient in AS compost due to its high biological activity.

The possible presence of phthalates with a long sidechain may be justified by their resistance to microbial attack during sludge treatment in wastewater plant. These phthalates were not clearly identified in this study, except for DEHP, as well as dinonyl phthalate whose presence was revealed by comparison with data from the NIST library.

The appearance of BBP only in the final steps of composting could be explained through a transesterification mechanism proposed by Cartwiright et al. [35], but in this case with an aromatic derivative "benzyl". This is in agreement with the high degree of aromaticity and polymerization observed in the last steps of composting, as shown in a previous study [38].

\subsection{Biodegradation of DEHP during composting}

In contrast to previous PAEs, the widespread industrial contaminant DEHP exhibited a continuous decrease during composting, but with different rates and behaviors in the two sludges (Figs. 3 and 4). First-order kinetics is frequently used to describe the biodegradation of a substrate at a low concentration and leads to the estimation of the biodegradation rates $[10,18,30]$. Therefore, the biodegradation rate of DEHP was calculated using a first-order kinetic model with a least squares fitting method. The half-lives of the first-order reaction can be calculated according to the equation:

$t_{2}=\frac{\ln 2}{K_{\mathrm{h}}}$

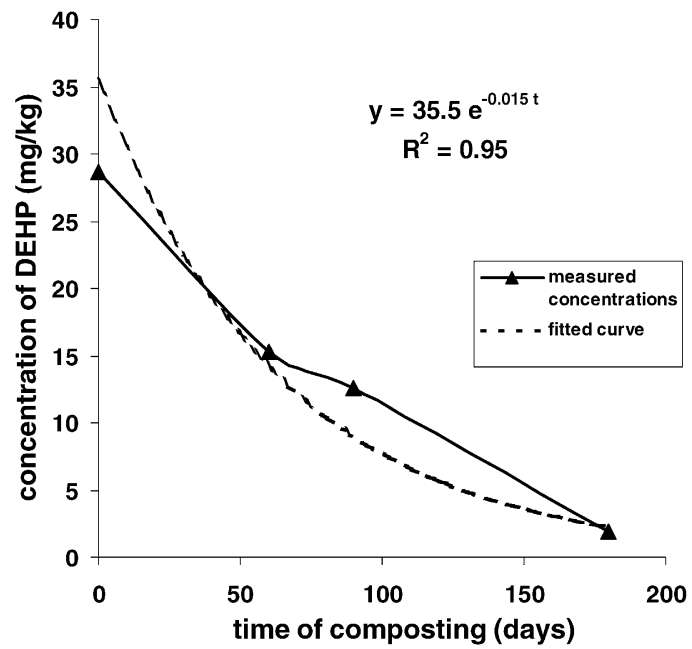

Fig. 3. Change of the concentration level of di-(2-ethyl-hexyl) phthalate (DEHP) during composting of lagooning sludge (LS) [characteristic ion 149 $m / z]$.

Table 4 summarizes the estimated values for kinetic constant, $K_{\mathrm{h}}$, with its relative standard deviation, and the halflife of DEHP during the composting of both lagooning and activated sludges.

Composting appears to be efficient in both cases for removal of DEHP. Madsen et al. [23] found that the firstorder kinetics rate $\left(K_{\mathrm{h}}\right)$ for DEHP removal from sludgeamended soil incubated under aerobic conditions was between $0.23 \times 10^{-2}$ day $^{-1}$ and $1.27 \times 10^{-2}$ day $^{-1}$, while $K_{\mathrm{h}}$ for sludge-amended soil incubated under anaerobic conditions $K_{\mathrm{h}}$ was of about $0.23 \times 10^{-2}$ day $^{-1}$. Gavala et al. [30] found the same range of values for the biodegradation of DEHP during mesophilic anaerobic digestion of sludge: about $0.35 \times 10^{-2}$ day $^{-1}$. Therefore, the much high rates determined in this study could reflect the aerobic conditions of medium.

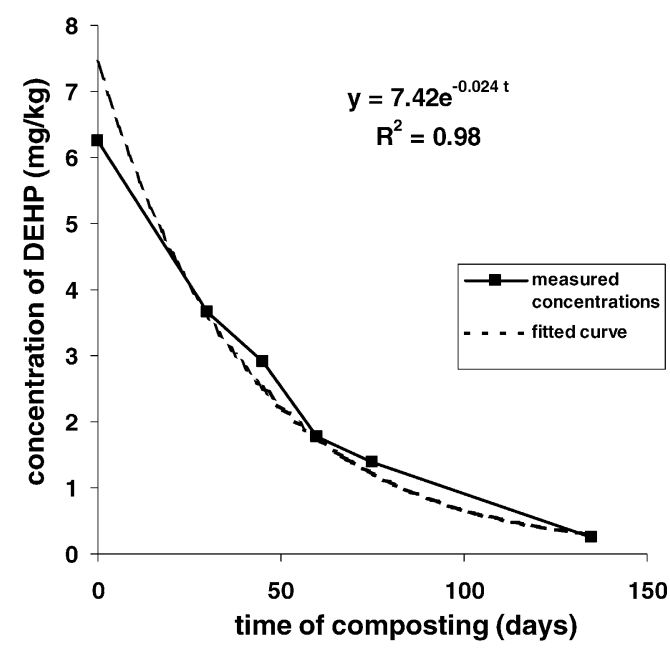

Fig. 4. Change of the concentration level of di-(2-ethyl-hexyl) phthalate (DEHP) during composting of activated sludge (AS) [characteristic ion 149 $\mathrm{m} / \mathrm{z}$. 
Table 4

Values of the kinetic constant of biodegradation, $K_{\mathrm{h}}$, and half-lives for di-(2ethyl-hexyl) phthalate (DEHP) during composting of both lagooning and activated sludges (characteristic ions: 149, 104, 76 and $70 \mathrm{~m} / \mathrm{z}$ )

\begin{tabular}{llll}
\hline Sludge & $\begin{array}{l}\text { Kinetic constant } \\
K_{\mathrm{h}}\left(\text { day }^{-1}\right)\end{array}$ & $\begin{array}{l}\text { Correlation } \\
\text { coefficient } R^{2}\end{array}$ & $\begin{array}{l}\text { Half-life } \\
t_{1 / 2} \text { (day) }\end{array}$ \\
\hline LS & $1.53 \times 10^{-2} \pm 0.03 \times 10^{-2}$ & 0.95 & 45.4 \\
AS & $2.4 \times 10^{-2} \pm 0.08 \times 10^{-2}$ & 0.98 & 28.9 \\
\hline
\end{tabular}

Comparison between the kinetic constants of biodegradation $K_{\mathrm{h}}$ and the half-lives of DEHP during composting of both AS and LS shows that the removal of DEHP is faster during AS composting compared to LS composting (Table 4). This may be justified by the presence of a wide class of indigenous microbial communities, developed during the treatment in the activated wastewater plant, and whose activity continues during the composting. In fact, the great rate of decomposition of raw organic material was recorded in the case of activated sludge (Table 1). The temperature could also be proposed as a physical factor contributing to DEHP biodegradation, since higher temperatures were reached in the AS compost (about $70^{\circ} \mathrm{C}$ ) than in $\mathrm{LS}$ compost (about $52{ }^{\circ} \mathrm{C}$ ) [39].

Moreover, the high initial level of DEHP in lagooning sludge (Fig. 3) may lead to an inhibition or toxic effect on the microbial biodegradation. Some studies show that high levels of DEHP or other recalcitrant PAEs in the medium compromise the removal of biodegradable PAEs $[28,30]$. It has been hypothesized that DEHP affects the membrane of the microbial cells thus causing the inhibition. In fact, this toxic effect of DEHP may also explain the appearance of PAEs with short alkyl side-chains during the last step of composting, after 60 days of AS composting and after 180 days of LS composting (Tables 2 and 3). This coincides with the removal of most DEHP from the medium; whose concentration level became less than $1.82 \pm 0.05 \mathrm{mg} / \mathrm{kg}$. So, the presence of high concentrations of DEHP in the early steps of treatment probably had an inhibition effect on the microbial decomposition of PAEs with longer alkyl side-chains into PAEs with short alkyl side-chains: BBP, DEP and DMP.

\subsection{De-esterification kinetics of both side-chains of DEHP}

The occurrence of mono(2-ethyl-hexyl) phthalate (MEHP) has been occasionally identified in the degradation pathways of DEHP. A compound with a retention time of 13.7 min was identified as MEHP by the NIST library. The presence of this metabolite suggests the involvement of the second catabolic pathway (Fig. 2), as proposed in previous studies, through hydrolysis or de-esterification of di-alkyl phthalates like DEHP to monoesters, such as MEHP, which can then be biotransformed into phthalic acid $[21,35]$. On the basis of the variation of the peak area with composting time, the rates of MEHP biodegradation were of about $1.1 \times 10^{-2}$ day $^{-1}$ for LS compost and of about $2.5 \times 10^{-2}$ day $^{-1}$ for AS compost. The rates of MEHP degradation are of the same order as those of DEHP, meaning that the biological process involved is the same for the two molecules: de-alkylation and de-esterification.

\section{Conclusion}

The occurrence and the fate of some phthalic acid esters PAEs targeted as priority pollutants by USEPA, were investigated during composting of both lagooning and activated sludges.

Di-ethyl-hexyl phthalate (DEHP) was the main PAE identified at high levels mainly in lagooning sludge (LS) but also in activated sludge (AS). The other PAEs in both sludges are unidentified or showed very low concentrations. During composting, removal of PAEs is suggested to occur through a degradation by microbial communities, which intensely developed in course of process. The microbial metabolism seems to begin by the decomposition of alkyl side-chains before aromatic ring-cleavage implying different catabolic pathways ( $\beta$-oxidation, demethylation or transesterification). The accumulation of PAEs with shorter alkyl chains in the last step of composting that originates from microbial attack of PAEs with longer alkyl side-chains cannot be interpreted as an increase of toxicity but as an intermediate stage of detoxification. The DEHP showed a biodegradation rate that followed a first-order kinetic model and was found to be higher for AS composting compared to LS composting. This was explained by a high microbial activity in AS compost, but the inhibition effect of high concentration of DEHP on biodegradation could be also suggested in LS compost. The appearance of BBP in the last step of composting could be attributed to transesterification reaction with aromatic derivatives that are prevailing in the end of composting. The occurrence of mono-ethyl-hexyl phthalates (MEHP) and their similar biodegradation rate to DEHP support that hydrolysis or dealkylation of each alkyl side-chain follows the same mechanism. Therefore, composting could be suggested as an important detoxification process for the removal of PAEs mainly DEHP from sludge, but sufficient time of treatment must be provided to achieve a good stabilization and safety of end product.

\section{Acknowledgements}

This work was supported by JER 6013 associated to the AUPELF-UREF and a Scholarship Program of Research Training from the French-Speaking University Agency.

\section{References}

[1] CEFIC, Plasticisers. A consideration of their impact on health and the environment. Plasticisers Sector Group, European Chemical Industry Federation, Brussels; 1989. 
[2] Wahl HG, Hoffmann A, Häring HU, Liebich HM. Identification of plasticizers in medical products by a combined direct thermodesorption-cooled injection system and gas chromatography-mass spectrometry. J Chromatogr A 1999;847:1-7.

[3] Kozumbo WJ, Kroll R, Rubin RJ. Assessment of mutagenicity of phthalates esters. Environ Health Perspect 1982;45:103-10.

[4] Huff JE, Kluwe WM. Phthalate esters carcinogenecityin F344/N rates and B6C3F mice. Prog Clin Biol Res 1984;141:131-54.

[5] USEPA. List of substances on IRIS. In: United State Environmental Protection Agency Integrated Risk System Information; 2000.

[6] Doull J, Cattley R, Elcombe C, Lake BG, Swenberg J, Wilkinson C, et al. A cancer risk assessment of di(2-ethylhexyl) phthalate: application of the new U.S. EPA Risk Assessment Guidelines. Regul Toxicol Pharmacol 1999;29:327-57.

[7] Bauer MJ, Herrmann R. Estimation of the environmental contamination by phthalic acid esters leaching from house-hold wastes. Sci Total Environ 1997;208:49-57.

[8] Lega R, Ladwig G, Meresz O, Clement RE, Crawford G, Salemi R, et al. Quantitative determination of organic priority pollutants in sewage sludge by GC/MS. Chemosphere 1997;34:1705-12.

[9] Schnaak W, Kuechler T, Kujawa M, Henschel KP, Suessenbach D, Donau R. Organic contaminants in sewage sludge and their ecotoxicological significance in the agricultural utilization of sewage sludge. Chemosphere 1997;35:5-11.

[10] Staples CA, Peterson DR, Parkerton TF, Adams WJ. The environmental fate of phthalate esters: a literature review. Chemosphere 1997;35:667-749.

[11] Banat FA, Prechtl S, Bischol F. Experimental assessment of bioreduction of di-2-ethylhexyl phthalate (DEHP) under aerobic thermophilic conditions. Chemosphere 1999;39:2097-106.

[12] Inman IC, Strachan SD, Sommer LE, Nelson DW. The decomposition of phthalates esters in soil. J Environ Sci Health Ser B 1984;19:24557.

[13] Johnson BT, Heitkamp MA, Jones JR. Environmental and chemical factors influencing the biodegradation of phthalic acid esters in freshwater, sediments. Environ Pollut 1984;8:101-18.

[14] Ribbons DW, Keyser P, Kunz DA, Taylor BF, Eaton RW, Anderson BN. Microbial degradation of phthalates. In: Gibson DT, editor. Microbial degradation of organic compounds. New York: Marcel Dekker; 1984. p. 371-97.

[15] Pujar BG, Ribbons DW. Phthalate metabolism in Pseudomonas fluorescens PHK purification and properties of 45-dihydroxyphthalate decarboxylase. App Environ Microb 1985;49:374-6.

[16] Chauret C, Mayfield CI, Inniss WE. Biotransformation of di- $n$-butyl phthalate by a psychrotrophic Pseudomonas fluorescens (BGW) isolated from subsurface environment. Can J Microbiol 1995;41: $54-63$.

[17] Wang J, Liu P, Shi H, Qian Y. Kinetics of phthalic acid ester degradation by acclimated activated sludge. Process Biochem 1997;32: $567-71$.

[18] Wang J, Chen L, Shi H, Qian Y. Microbial degradation of phthalic acid esters under anaerobic digestion of sludge. Chemosphere 2000;41: $1245-8$.

[19] O'Grady DP, Howard PH, Warner AF. Activated-sludge biodegradation of 12 commercial phthalate-esters. Appl Environ Microbiol 1985;49:443-5.
[20] Eljertsson J, Alnervik M, Jonsson S, Svensson BH. Influence of water solubility, side-chain degradability and side-chain structure on the degradation of phthalic acid esters under methanogenic conditions. Environ Sci Technol 1997;31:2761-4.

[21] Shelton DR, Boy SA, Tiedje JM. Anaerobic degradation of phthalic acid esters in sludge. Environ Sci Technol 1984;18:93-7.

[22] Roslev P, Madsen PL, Thyme JB, Henriksen K. Degradation of phthalate and di-(2-ethylhexyl)phthalate by indigenous and inoculated microorganisms in sludge-amended soil. Appl Environ Microbiol 1998;64:4711-9.

[23] Madsen PL, Thyme JB, Henriksen K, Moldrup P, Roslev P. Kinetics of di-(2-ethylhexylphthalate mineralisation in sludge-amended soil Environ Sci Technol 1999;33:2601-6.

[24] USEPA. National Sewage Sludge Survey. Fed Reg 55218; 1990. p. 47210-83.

[25] Webber MD, Lesage S. Organic contaminants in Canadian municipal sludges. Waste Manage Res 1989;7:63-82.

[26] Subba-Rao RV, Rubin HE, Alexander M. Kinetics and extent of mineralization of organic chemicals at trace levels in freshwater and sewage. Appl Environ Microbiol 1982;43:1139-50.

[27] Battersby NS, Wilson V. Survey of the anaerobic biodegradation potential of organic chemicals in digesting sludge. Appl Environ Microbiol 1989;55:433-9.

[28] Alatriste-Mondragon F, Iranpour R, Ahring BK. Toxicity of di-(2ethylhexyl) phthalate on the anaerobic digestion of wastewater sludge. Water Res 2003;37:1260-9.

[29] O'Connor OA, Rivera MD, Young LY. Toxicity and biodegradation of phthalic acid esters under methanogenic conditions. Environ Toxicol Chem 1989;8:569-76.

[30] Gavala HN, Alatriste-Mondragon F, Iranpour R, Ahring BK. Biodegradation of phthalate esters during the mesophilic anaerobic digestion of sludge. Chemosphere 2003;52:673-82.

[31] Engelhardt G, Wallnofer PR, Hutzinger O. Microbial metabolism of di- $n$-butyl phthalate and related dialkyl phthalates. Bull Environ Contam Toxicol 1975;13:342-7.

[32] Kurane R, Suzuki T, Takahara Y. Methabolic pathway of phthalate ester by Nocardia erythropolis. Agric Biol Chem 1980;44:523-7.

[33] Taylor BF, Ribbons DW. Bacterial decarboxylation of $o$-phthalic acids. Appl Environ Microbiol 1983;46:1276-81.

[34] Dutton JR, Venables WA, Saint CP. Comamonas acidovorans UCC61 catabolizes $o$-phthalates via a 45 -oxygenation pathway that is encoded on $70 \mathrm{~kb}$ section of plasmid pOPH1 bounded by directly repeated sequences. Microbiology 1995;141:1673-82.

[35] Cartwright CD, Owen SA, Thompson IA, Burns RG. Biodegradation of diethyl phthalate in soil by a novel pathway. FEMS Microbiol Lett 2000;186:27-34.

[36] Niazi JH, Prasad DT, Karegoudar TB. Initial degradation of dimethylphthalate by esterases from Bacillus species. FEMS Microbiol Lett 2000;196:201-5.

[37] Wang J, Liu P, Qian Y. Microbial metabolism of di-butyl phthalate (DBP) by a denitrifying bacterium. Process Biochem 1999;34:745-9.

[38] Amir S, Hafidi M, Bailly JR, Revel JC. Characterization of humic acids extracted from sewage sludge during composting and of their Sephadex gel fractions. Agronomie 2003;23:269-75.

[39] Amir S, Hafidi M. Valorisation de boues de stations d'épuration des eaux usées par un bioprocédé aérobie "compostage". Ann Chim Sci Mater 2001;26:S409-14. 